\title{
The deterioration of tall wheatgrass pastures on saline sodic soils
}

\author{
MIGUEL A. TABOADA, GERARDO RUBIO, AND RAUL S. LAVADO
}

Authors are assistant professors and head professor, Departamento de Suelos, Facultad de Agronomia, Universidad de Buenos Aires, Av. San Martin 4453, 1417 Buenos Aires, Argentina. At the time of the research, the senior author was fellowship, Consejo Nacional de Investigaciones Cientificas y Téchnicas (CONICET).

\begin{abstract}
The deterioration of sown tall wheatgrass (Elytrigia elongata) growing on 3 sodic saline soils was investigated in the Laprida basin, in the center of the Buenos Aires province of Argentina. These soils are known to have poor drainage and high saline levels and support different species associations. On each soil type the native grassland was compared to sown wheatgrass, in terms of plant density and cover and soil physical and chemical characteristics. The 3 soil types reacted differently to tillage. Tillage had little impact on soil type A (typic Natraquoll), a poorly drained soil with a loamy A horizon $(14 \mathrm{~cm})$ overlying a silty clay loam. Soil type B (typic Natraquaf), a wet texture contrast soil with bleached horizons has characteristics that are likely to severely limit plant growth. The sowing of wheatgrass increased ground cover by live vegetation on this soil type. This contrasted with soil type $\mathbf{C}$ (typic Natralboll), a saline soil with an organic matterrich but thin $(8 \mathrm{~cm}) A$ horizon. In this soil, the plant density declined and other components such as pasture cover also declined with time. This pasture deterioration was attributed to several soil factors including decreased organic matter content and increased soil bulk density. It was concluded that the varied performance of wheatgrass sown pastures was a function of the different inherent characteristics of the soils.
\end{abstract}

Key Words: tall wheatgrass pastures, native grasslands, tillage, deterioration, saline-sodic soils

Salt-affected soils are distributed worldwide, amounting to some 77,925,000 $\mathrm{km}^{2}$ (Gupta and Abrol 1990). Those found in wet areas generally have high exchangeable sodium percentage throughout the profile, especially in the clay subsoil (Szabolcs 1988). The depth of the A horizon in these sodic soils is a very important feature, because it contains most of the organic matter and nutrients, and also determines plant water availability (Malhi et al. 1992, Szabolcs 1988). Breakdown of topsoil aggregates under tillage may result in cloddy and structurally unstable seedbeds, surface crusting and in reduced water infiltration leading to restricted plant establishment, growth and yield (Gupta and Abrol 1990, Rengasamy and Olsson 1991, Rengasamy et al. 1984). These soils compact at the surface when grazed, especially

Research was funded by CONICET, Grant 9780-86.

Manuscript accepted 21 Jun. 1997.
Se investigó el deterioro de pasturas de agropiro (Elytrigia elongata), sembradas sobre tres suelos salino-sódicos de la depresión de Laprida (centro de la provincia de Buenos Aires, Argentina). Estos suelos se caracterizan por su pobre drenaje y altos nieveles de salinidad, y soportan diferentes comunidades vegetales. En cada tipo de suelo se comparó el pastizal nativo contra la pastura sembrada de agropiro, en términos de la densidad y cobertura de plantas, y características físicas y químicas de los suelos. Los tres tipos de suelo respondieron diferente a las labranzas. El laboreo afectó poco al suelo tipo A Natracuol típico), el cual es pobremente drenado y posee un horizonte Ah (14 $\mathrm{cm}$ ) franco sobre un horizonte franco limo arcilloso. El suelo tipo B (Natracualf típico), con texturas contrastantes y horizontes eluviados, posee características que limitan severamente el creimiento de las plantas. En este suelo, la siembra de agropiro incrementó la cobertura superficial por vegetación viva. Ello contrastó con el suelo tipo $\mathbf{C}$ (Natralbol típico), salino y con un horizonte A rico en materia orgánica, pero somero $(8 \mathrm{~cm})$. En este suelo, la densidad de plantas declinó y otros componentes, como la cobertura de la pastura, también declinaron con el tiempo. Este deterioro de la pastura fue atribuido a una serie de factores edáficos, que incluyen el descenso en el contenido de materia orgánica y el aumento en la densidad aparente. Se concluyó que la distinta performance de las pasturas de agropiro fue causada por las características particulares de los suelos.

with repeated treading when wet (Mulholland and Fullen 1991). In addition, the very hard and compact $\mathrm{Bt}$ horizon limits water and air movements as well as root elongation (Malhi et al. 1992, Szabolcs 1988). Plant development and crop production can also be restricted by the phytotoxic effects of excess exchangeable sodium (Gupta and Abrol 1990).

Since these limitations restrict the growth of high yielding crops, most sodic soils are used for grazing cnterprises. Native grasses produce most of the forage available to livestock. Although adapted to the environmental constraints, native species have low productivity and are sometimes unpalatable (Bowman et al. 1985). Exotic grasses are often sown to improve the supply and quality of forage in these areas. Tall wheatgrass (Elytrigia elongata) is the most commonly used species for this purpose (Ludwig and McGinnies 1978, Malcolm 1986, Malcolm and 
Clarke 1973). It is popular because it is highly productive and also it tolerates salts, sodium and water stresses, and waterlogging (Frelich et al. 1973, Ludwig and McGinnies 1978, Malcolm 1986, Pearson and Bernstein 1958).

Replacing native grasslands with sown tall wheatgrass pastures is also an accepted practice in Argentina (Hidalgo et al. 1989, Maddaloni 1986). However, tall wheatgrass pastures are not always profitable because soil type is not always taken into account (Batista et al. 1993). Tall wheatgrass plants disappear progressively within a few years from sowing and native grasses and weeds invade the site (Oesterheld and León 1987). Bare ground also increases as the pastures degenerate. This paper aims to determine if soil factors are responsible for this process of pasture deterioration. We hypothesize: i) that pasture deterioration is caused by the uneven response to tillage of soils with different surface horizon depths; and ii) that the higher the exchangeable sodium in the soil, the more detrimental are the changes caused by tillage to the seeded pasture.

\section{Study Area}

This study was carried out on a cattle breeding ranch, located in the Laprida basin at the center of the Buenos Aires province of Argentina $\left(37^{\circ} 20^{\prime} \mathrm{S}\right.$ and $60^{\circ} 43^{\prime} \mathrm{W}, 420 \mathrm{~km}$ south west of Buenos Aires city). This region has a mean annual temperature of $14^{\circ} \mathrm{C}\left(20.8^{\circ} \mathrm{C}\right.$ in summer and $7.3^{\circ} \mathrm{C}$ in winter $)$ and a mean annual rainfall of $750 \mathrm{~mm}$, evenly distributed throughout the year. The soils are developed over aeolian loess-like deposits. Apart from some upland soils, this low-lying region mainly consists of different kinds of sodic saline-saturated soils (Batista et al. 1993, Salazar Lea Plaza and Moscatelli 1989). These soils have a hard Bt horizon (clay subsoil), but vary in their topsoil properties (i.e.

Table 1. Description of the studied soil types and associated floristic composition.

\begin{tabular}{lcll}
\hline \hline & \multicolumn{3}{c}{ Soil type A (typic Natraquoll) } \\
Horizon & Depth (cm) & Texture & Structure \\
\hline Ah & $0-14$ & loam & subang.blocks \\
BA & $14-21$ & silty loam & subang.blocks \\
Bt & $21-+$ & silty clay loam & prisms (ang. blocks) \\
\hline
\end{tabular}

\section{Floristic composition:}

Setaria geniculata, Stenotaphrum secundatum, Distichlis spicata, D.scoparia Eryngium ebracteatum, Aster squamatus, Stipa formicarum, Panicum bergii and Juncus balticus.

\begin{tabular}{lcll}
\hline & \multicolumn{2}{c}{ Soil type B (typic Natraqualf) } \\
Horizon & Depth (cm) & Texture & Structure \\
\hline $\mathbf{E}$ & $0-11$ & loam & massive \\
Bt & $11-28$ & clay loam & columns (ang. blocks) \\
\hline
\end{tabular}

Floristic composition:

Distichlis spicata, D. scoparia, Sporobolus indicus, Diplachne uninerva, Lepidium sp., and Nostoc sp.

\begin{tabular}{lcll}
\hline & \multicolumn{2}{c}{ Soil type C (typic Natralboll) } \\
Horizon & Depth (cm) & Texture & Structure \\
\hline $\mathbf{A h}$ & $0-8$ & loam & subang .blocks \\
$\mathbf{E}$ & $8-20$ & loam & massive \\
$\mathbf{B t}$ & $20-45$ & silty clay loam & prisms (ang. blocks) \\
\hline
\end{tabular}

Floristic composition:

Paspalum vaginatum, Leersia hexandra, Eleocharis bonariensis, Eryngium echinatum, and Phyla canescens.
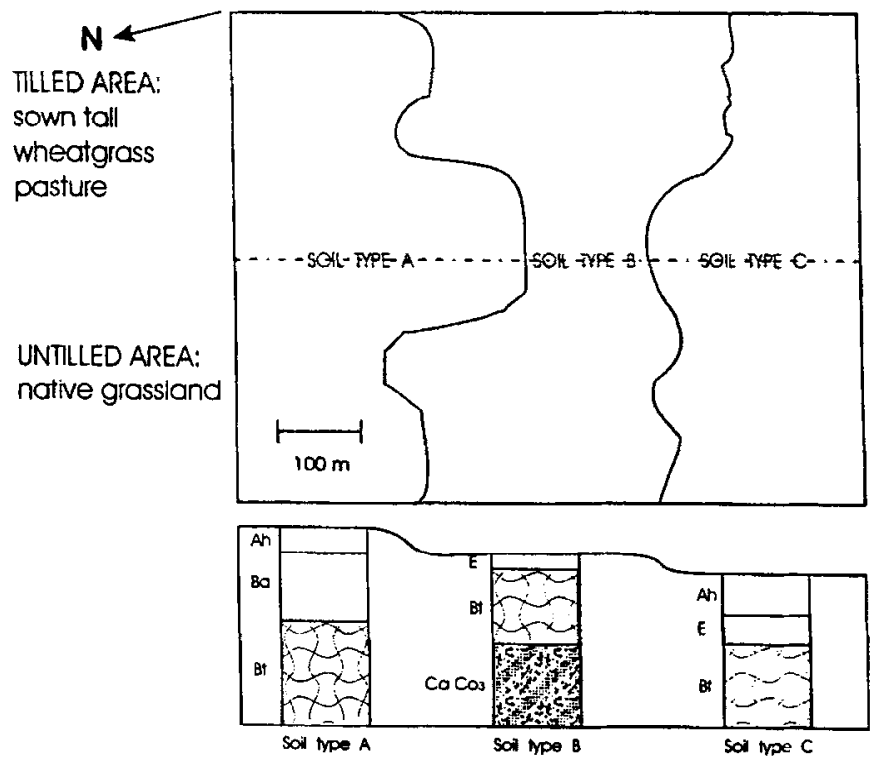

Fig. 1. Spatial distribution of the studied soil types and treatments.

depth, organic matter content and sodicity). Different native grassland communities are associated with each soil, each community with its particular species composition and productivity (Batista et al. 1993). These soil-vegetation units are distributed in a heterogeneous landscape pattern (Batista et al. 1993, Salazar Lea Plaza and Moscatelli 1989).

The study was conducted from August 1987 to August 1988 on a 200 ha area of the ranch, covered by 3 different soil types here called A, B, and C (Fig. 1, Table 1). Soil type A (typic Natraquoll) has a loamy A horizon overlying a poorly drained, sodic, silty clay loam. This soil represents a better quality site than the other 2. Soil type B (typic Natraqualf), which is a wet texture contrast soil with bleached horizons and high sodicity, has a lower capacity for crop production. Soil type $\mathrm{C}$ (typic Natralboll) is characterized by an organic matter rich but thin $A$ horizon. This soil occupies the lowest topographic positions and is subject to longer periods under surface ponding.

The entire area was divided into 2 adjacent 100 ha fields, representing 2 treatments; i) untilled; a native pasture which had never been plowed; ii) tilled: a field disc-harrowed twice at $15 \mathrm{~cm}$ depth and sown with a tall wheatgrass (Elytrigia elongata) pasture in March 1985. Following establishment of the wheatgrass both paddocks were continuously stocked by sheep and cattle $(1: 2$ ratio) all year round at the rate of $0.7-1.0$ animal units ha- ${ }^{-1}$. The 3 soil types were identified in each of the treatment areas.

\section{Methods}

Ground cover of litter and live vegetation (native grasses and tall wheatgrass), and bare surface were determined on 3 occasions, using the point method (Mueller-Dombois and Ellemberg 1974). This method involved dropping a needle every $0.10 \mathrm{~m}$ along ten, 2-m transects distributed at random in each wheatgrass $X$ soil type treatment. The total number of points sampled was 200 per soil type. Tall wheatgrass tussocks density was determined from the mean of ten, $0.60 \times 0.60 \mathrm{~m}$ plots randomly distributed within each wheatgrass $X$ soil type treatment. 
Determinations of soil particle size distribution (by the pipette method), organic carbon content (by the Walkley and Black method) and $\mathrm{pH}$ (in paste), were undertaken in topsoil samples taken at random in the tilled and untilled areas at the start of the experiment. At the beginning and the end of the experiment, salinity was measured in 6 topsoil samples as electrical conductivity of saturation extracts (Rhoades 1982). The Sodium Adsorption Ratio $\left(\mathrm{SAR}=\left[\mathrm{NA}^{+}\right] /\left[\mathrm{Ca}^{++}+\mathrm{Mg}^{++}\right]^{1 / 2}\left(\mathrm{mmol}^{+1} \mathrm{lit}^{-1}\right)\right.$ was calculated from cation concentrations determined on saturated extracts (atomic absorption spectrophotometry). Six topsoil samples per soil unit were taken 5 times during the study to determine gravimetric water content (SWC) by oven-drying and bulk density (BD) measured by the core method. On the same dates, 30 measurements of soil penetration resistance (PR) were performed using the Proctor penetrometer (Davidson 1965). The PR values were adjusted to an oven-dry basis using fitted linear SWC-PR regressions.

\section{Statistics}

The experimental site was selected on the basis of our previous detailed geomorphological, soil, and vegetation maps of this area (Batista et al. 1993). This previous knowledge allowed us to assume that tilled and untilled areas were similar in both soil and vegetation prior to the start of the experiment and, therefore, observed differences were attributed to the treatments. Spatial arrangement of the 3 soil types in the paddock (Fig. 1) did not allow for treatments to be replicated in space. As a consequence, the implied level of statistical inference does not go beyond the soil types examined in this study. (Hurlbert 1984). Means and standard errors are provided. In addition, results were statistically analyzed as a paired experiment (Montgomery 1991), in which the probability of the mean UT-T difference $\neq 0$ (2-tailed $t$ test) was tested and where the successive sampling dates were the replicates.

\section{Results and Discussion}

\section{Soil type "A"}

Tillage had little influence on the measured vegetation parameters (Table 2), as $P$ values of mean differences $\neq 0$ ranged from 0.07 to 0.18 . The litter component was lower in tilled areas in 2 of the 3 studied dates, and a greater amount of bare surface was found under sown pasture in August 1988. Tall wheatgrass dominated $(84-98 \%)$ the live components of the tilled treatment in December 1987 and August 1988, but native species accounted for half the live plant cover in March 1988 (Table 2).

The typic Natraquoll soil of this area did not change significantly from the untilled to the tilled area. The $P$ values of mean differences $\neq$ on the 5 studied dates ranged from 0.10 to 0.95 . Only pH decreased slightly, but was still within the neutrality range (Table 3; Figs. $3 \mathrm{a}, \mathrm{b}$, and c). The well-developed A horizon of this soil was not mixed with the underlying silty loam subsoil during seedbed preparation. The tilled area retained the original desirable topsoil conditions, which probably contributed to the successful establishment of the sown pasture. Two to 3 years after sowing, this pasture still had the highest density of tall wheatgrass tussocks (Fig. 2). Hidalgo et al. (1989) also found a great abundance of tall wheatgrass in a 3-year-old sown pasture, growing on Natraquolls in the same area. They reported that the productivity of the tall wheatgrass pasture did not differ significantly from that of the native grassland which suggests that the replacement would not be economically profitable.

Table 2. Components of the ground basal cover in the untilled (UT) and tilled (T) fields (means and standard errors).

\begin{tabular}{|c|c|c|c|c|c|c|}
\hline \multirow{3}{*}{ Soil type A } & \multicolumn{6}{|c|}{ Ground basal cover } \\
\hline & \multicolumn{2}{|c|}{ December 1987} & \multicolumn{2}{|c|}{ March 1988} & \multicolumn{2}{|c|}{ August 1988} \\
\hline & UT & $\mathbf{T}$ & UT & $\mathrm{T}$ & $\overline{\mathrm{UT}}$ & $\bar{T}$ \\
\hline \multirow{7}{*}{$\begin{array}{l}\text { Bare surface } \\
\text { a) Litter } \\
\text { b) Native species } \\
\text { c) Tall wheatgrass } \\
\text { d) Live }(b+c)\end{array}$} & \multicolumn{4}{|c|}{$\ldots \ldots \ldots \ldots(\%)$} & \multicolumn{2}{|r|}{ 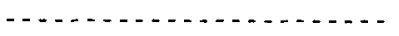 } \\
\hline & $12.50 \pm 3.19$ & $16.50 \pm 2.69$ & $3.50 \pm 1.58$ & $9.50 \pm 3.45$ & $1.50 \pm 0.76$ & $21.00 \pm 4.52$ \\
\hline & $70.50 \pm 5.08$ & $61.00 \pm 4.40$ & $79.00 \pm 2.34$ & $52.50 \pm 5.23$ & $83.50 \pm 3.42$ & $55.00 \pm 5.78$ \\
\hline & $17.00 \pm 3.89$ & $0.50 \pm 0.50$ & $17.50 \pm 3.10$ & $19.50 \pm 6.44$ & $14.50 \pm 3.12$ & $3.50 \pm 1.07$ \\
\hline & - & $22.00 \pm 2.91$ & - & $15.50 \pm 3.37$ & - & $19.50 \pm 2.63$ \\
\hline & $17.00 \pm 3.89$ & $22.50 \pm 3.10$ & $17.50 \pm 3.10$ & $35.00 \pm 6.29$ & $14.50 \pm 3.12$ & $23.00 \pm 2.81$ \\
\hline & \multirow{2}{*}{\multicolumn{4}{|c|}{ December 1987}} & & \\
\hline \multirow[t]{2}{*}{ Soil type B } & & & & & \multicolumn{2}{|c|}{ August 1988} \\
\hline & UT & $\mathrm{T}$ & UT & $\mathrm{T}$ & UT & $\mathrm{T}$ \\
\hline \multirow{6}{*}{$\begin{array}{l}\text { Bare surface } \\
\text { a) Litter } \\
\text { b) Native species } \\
\text { c) Tall wheatgrass } \\
\text { d) Live }(b+c)\end{array}$} & \multicolumn{4}{|c|}{$\ldots \ldots \ldots \ldots \ldots(\%)$} & $\ldots$ & - - - - - \\
\hline & \multirow{5}{*}{$\begin{array}{r}45.50 \pm 5.65 \\
46.60 \pm 4.07 \\
8.50 \pm 2.12 \\
- \\
8.50 \pm 2.12\end{array}$} & $31.50 \pm 3.88$ & \multirow{5}{*}{$\begin{array}{c}38.50 \pm 4.35 \\
47.00 \pm 5.64 \\
14.00 \pm 2.77 \\
- \\
14.00 \pm 2.77\end{array}$} & $39.00 \pm 4.40$ & $20.00 \pm 3.88$ & $12.50 \pm 2.61$ \\
\hline & & $51.00 \pm 4.46$ & & $36.50 \pm 4.29$ & $67.50 \pm 4.17$ & $67.00 \pm 3.67$ \\
\hline & & $7.00 \pm 2.26$ & & $10.50 \pm 2.93$ & $12.50 \pm 2.01$ & $2.50 \pm 1.12$ \\
\hline & & $10.50 \pm 2.17$ & & $14.00 \pm 2.56$ & $18.00 \pm 3.18$ & \\
\hline & & $17.50 \pm 3.01$ & & $24.50 \pm 3.45$ & $12.50 \pm 2.01$ & $20.50 \pm 3.35$ \\
\hline \multirow[t]{2}{*}{ Soil type C } & \multicolumn{4}{|c|}{$\begin{array}{r}\text { Ground basal cover } \\
\text { March } 1988\end{array}$} & \multicolumn{2}{|c|}{ August 1988} \\
\hline & UT & $\mathrm{T}$ & UT & $\mathrm{T}$ & UT & $\mathrm{T}$ \\
\hline \multirow{6}{*}{$\begin{array}{l}\text { Bare surface } \\
\text { a) Litter } \\
\text { b) Native species } \\
\text { c) Tall wheatgrass } \\
\text { d) Live }(b+c)\end{array}$} & \multicolumn{4}{|c|}{$\ldots \ldots \ldots \ldots+\ldots(\%)$} & $\ldots \ldots$ & $\ldots \ldots$ \\
\hline & $2.00 \pm 1.53$ & $12.00 \pm 2.14$ & 0 & $15.00 \pm 5.33$ & 0 & $13.50 \pm 2.48$ \\
\hline & $88.00 \pm 3.74$ & $74.00 \pm 3.32$ & $67.50 \pm 5.88$ & $62.50 \pm 5.74$ & $70.00 \pm 4.41$ & $67.50 \pm 4.37$ \\
\hline & $9.50 \pm 3.20$ & $6.50 \pm 2.24$ & $30.50 \pm 6.56$ & $11.00 \pm 1.63$ & $30.00 \pm 4.41$ & $3.00 \pm 1.53$ \\
\hline & - & $6.00 \pm 2.56$ & - & $11.50 \pm 2.24$ & - & $16.00 \pm 2.67$ \\
\hline & $9.50 \pm 3.20$ & $12.50 \pm 1.86$ & $30.50 \pm 6.56$ & $22.50 \pm 2.39$ & $30.00 \pm 4.41$ & $19.00 \pm 3.06$ \\
\hline
\end{tabular}




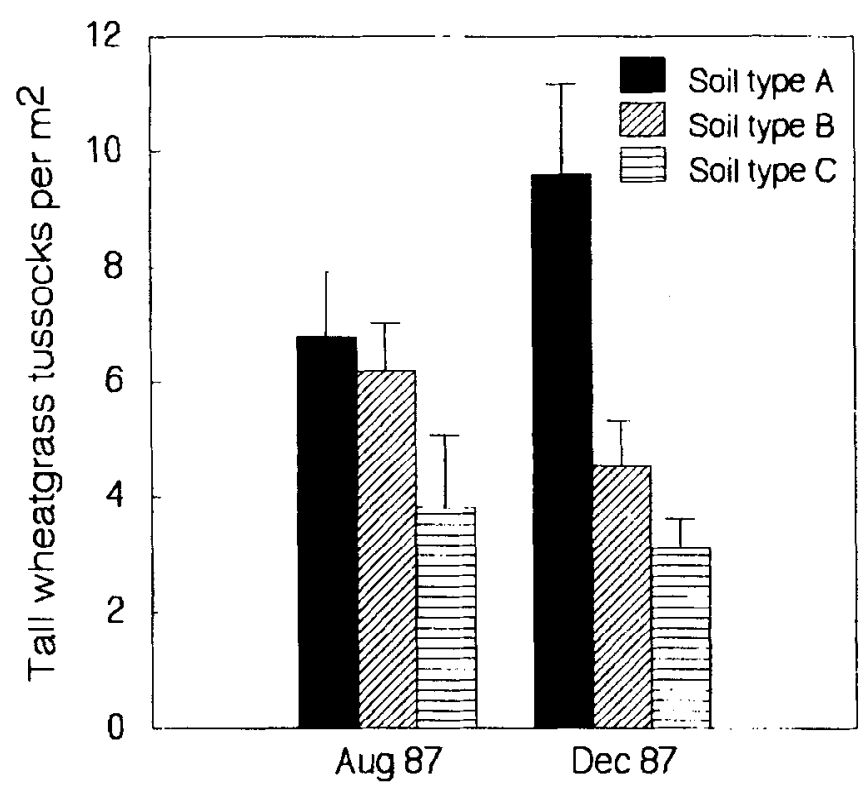

Fig. 2. Density of tall wheatgrass tussocks in each soil type. Bars are standard errors.

\section{Soil Type "B"}

This soil had the most severe constraints for plant establishment and growth and, for that reason, the most bare surface. It was only in this soil type that algae (Nostoc sp) appeared as an important component of the plant community (Table 1). Ground cover of live vegetation was significantly higher $(P<0.01)$ in tilled areas on all sampling occasions, while the other studied vegetation parameters were similar between areas $(P=0.24-0.67)$. The density of tall wheatgrass tussocks was intermediate among the 3 soil types (Fig. 2). Live cover of tall wheatgrass ranged from $51 \%$ in March 1988 to $84 \%$ in August 1988. The very thin surface horizon was mixed with the underlying clay loam subsoil when tilled. This increased silt and clay percentages, $\mathrm{pH}$, electrical conductivity, and SAR in tilled areas, but reduced organic carbon content (Table 3 ). The physical properties of the soil were improved after tillage, by lowering ( $P<0.01)$ bulk density in the topsoil (Fig. 4 b). Soil water content $(P=0.49)$ and the adjusted penetration resistance $(P=$ 0.13 ) were similar between areas (Figs. $4 \mathrm{a}$ and c). The lower bulk density cannot be ascribed to tillage, as macropores created by tillage cannot be expected to persist in this highly sodic environment (Rengasamy and Olsson 1991). Rather it was due to the creation of large pores by the dense root system of tall wheatgrass.

Vegetation showed positive changes in the tilled field. The native community of this land class is largely dominated by salt-

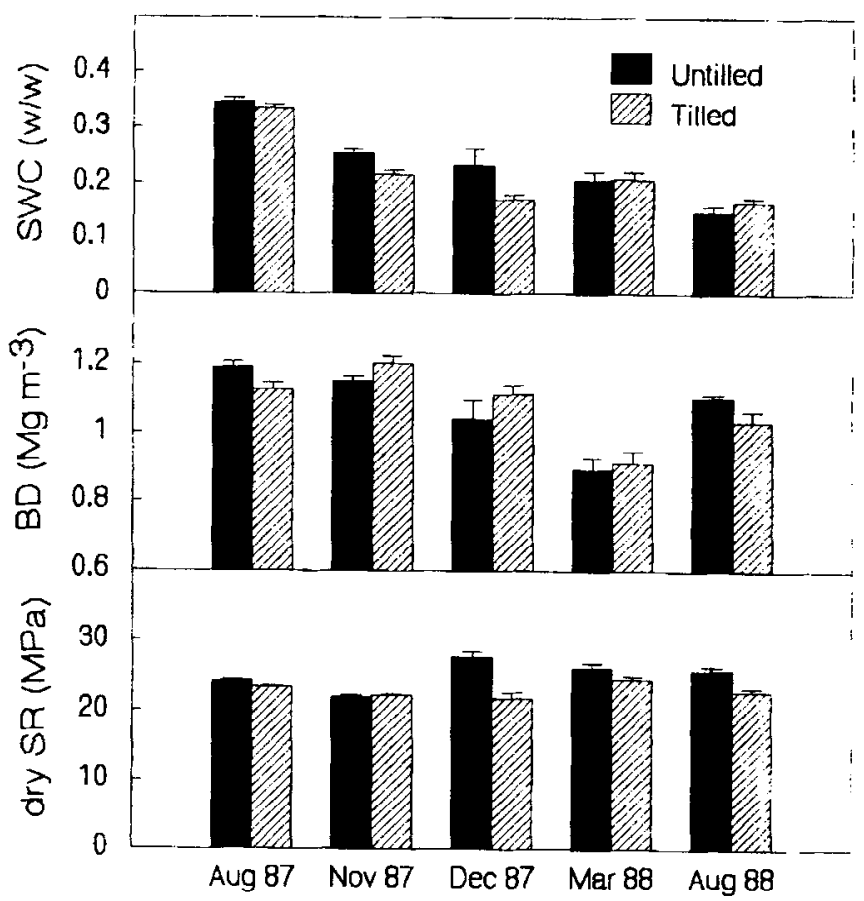

Fig. 3. Topsoil water content (SWC) (a), bulk density (BD) (b) and ovendry surface penetration resistance (dry $P R$ ) in soil type $A$ (typic Natraquoll). Bars are standard errors.

grass (Distichlis spicata and D. scoparia), a low producing, largely unpalatable species (Bowman et al. 1985). The replacement of this undesirable forage by tall wheatgrass was successful, as shown by the significantly higher live vegetation and moderate density of tall wheatgrass tussocks found in the tilled field. The increase of the sodicity in topsoil is unlikely to affect the persistence of tall wheatgrass because of its well-known high tolerance to alkali stresses (Malcolm 1986, Pearson and Bernstein 1958). The amelioration of the conditions of a nearby Natraqualf after planting tall wheatgrass was also found by Irigoyen and Giambiagi (1990).

\section{Soil type "C"}

Unlike the other soil types, the sown pastures in this soil showed signs of failing. The bare surface, negligible in the untilled field, was significantly higher $(P<0.05)$ in the tilled area. Both litter and live vegetation were affected to a lesser degree by tillage (Table 2). Tall wheatgrass density was the lowest among the soil types (Fig. 2). Its proportion within the live

Table 3. Particle-size analysis, organic carbon (OC), pH in paste, sodium adsorption ratio (SAR) and soil salinity as measured by its electrical conductivity (EC) in the untilled (CT) and the tilled (T) top horizons. Means and standard errurs.

\begin{tabular}{|c|c|c|c|c|c|c|}
\hline & UT & $\mathrm{T}$ & UT & $\mathrm{T}$ & UTT & $\mathbf{T}$ \\
\hline Sand (\% w) & $34.45 \pm 1.55$ & $32.70 \pm 0.50$ & $46.15 \pm 2.05$ & $26.60 \pm 1.00$ & $30.50 \pm 0.40$ & $26.00 \pm 1.80$ \\
\hline Silt (\% w) & $44.50 \pm 1.50$ & $41.25 \pm 0.05$ & $28.01 \pm 3.40$ & $49.55 \pm 0.15$ & $45.50 \pm 0.15$ & $52.25 \pm 0.91$ \\
\hline Clay (\% w) & $21.05 \pm 0.05$ & $25.55 \pm 0.05$ & $15.84 \pm 1.36$ & $23.85 \pm 0.85$ & $23.95 \pm 0.25$ & $21.76 \pm 0.90$ \\
\hline$O C(\% w)$ & $1.87 \pm 0.04$ & $1.78 \pm 0.08$ & $1.03 \pm 0.03$ & $0.75 \pm 0.07$ & $4.52 \pm 0.05$ & $2.17 \pm 0.38$ \\
\hline pH (paste) & $7.65 \pm 0.31$ & $6.87 \pm 0.14$ & $8.78 \pm 0.18$ & $9.01 \pm 0.13$ & $7.04 \pm 0.09$ & $7.40 \pm 0.08$ \\
\hline SAR & $37.26 \pm 10.8$ & $25.83 \pm 1.02$ & $28.43 \pm 5.18$ & $47.73 \pm 0$ & $25.03 \pm 0.25$ & $31.18 \pm 6.01$ \\
\hline \multicolumn{7}{|l|}{$\mathrm{EC}(\mathrm{dS} / \mathrm{m})$} \\
\hline August 87 & $1.77 \pm 0.16$ & $1.23 \pm 0.13$ & $2.48 \pm 0.34$ & $3.49 \pm 0.69$ & $1.20 \pm 0.12$ & $1.90 \pm 0.19$ \\
\hline August 88 & $3.67 \pm 0.81$ & $3.74 \pm 0.63$ & $2.82 \pm 0.43$ & $3.90 \pm 0.40$ & $1.31 \pm 0.05$ & $3.01 \pm 0.34$ \\
\hline
\end{tabular}




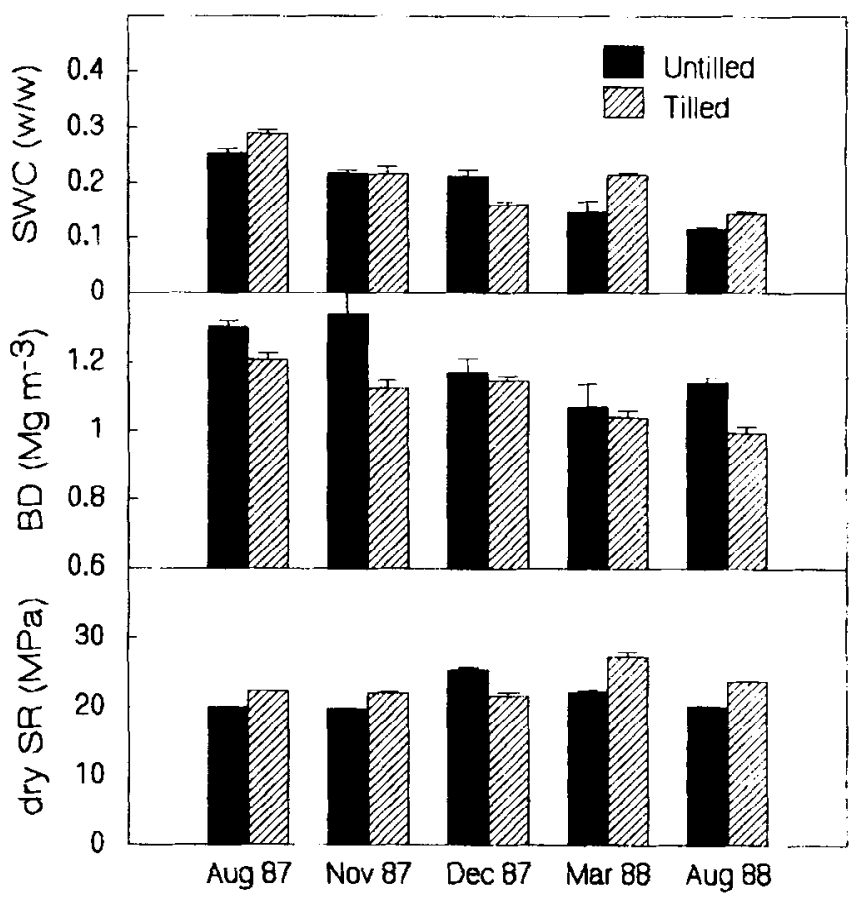

Fig. 4. Topsoil water content (SWC) (a), bulk density (BD) (b) and ovendry surface penetration resistance (dry $P R$ ) in soil type $B$ (typic Natraquali). Bars are standard errors.

component of the pasture was around $50 \%$ both in December 1987 and in March 1988 but reached 84\% in August 1988 (Table 2). This deterioration cannot be ascribed to a single factor, but rather to the combination of several soil properties affected by tillage. This soil type (typic Natralboll) has an organic matter-rich but thin Ah horizon overlying an infertile E horizon (Table 1). Tillage reduced organic matter content in the Ah horizon to less than half that in untilled areas (Table 3), which restricted plant nutrient supply. Silt percentage was higher when plowed resulting in a change in soil texture from loam to silty loam. After soil physical properties also deteriorated following tillage (Figs. 5 a, $b$, and c). Soil water content was significantly lower $(P<0.05)$, bulk density, originally low in this soil, was significantly increased $(\mathrm{P}<0.05)$ and the adjusted penetration resistance was significantly lower $(P<0.01)$. Livestock trampling is a key factor in the increase in bulk density (Mullholland and Fullen 1991). In such conditions, germination, establishment, and persistence of wheatgrass would be difficult (Frelich et al. 1973, Gupta and Abrol 1990). Bare surfaces facilitated the upward movement of both water and soluble salts to the surface (Lavado and Taboada 1988). This must account for the lower water content and higher electrical conductivity found in the tilled topsoil (Table 3). In contrast, neither pH nor SAR varied between the fields (Table 3). Although salinity as high as $\mathrm{EC}=3.01 \mathrm{dS} \mathrm{m}^{-1}$ would not be critical for tall wheatgrass (Malcolm 1986), it could affect the survival of hydrophilous native grasses existing in this community, This possibly prevented the regrowth of native species among tall wheatgrass tussocks in the tilled field.

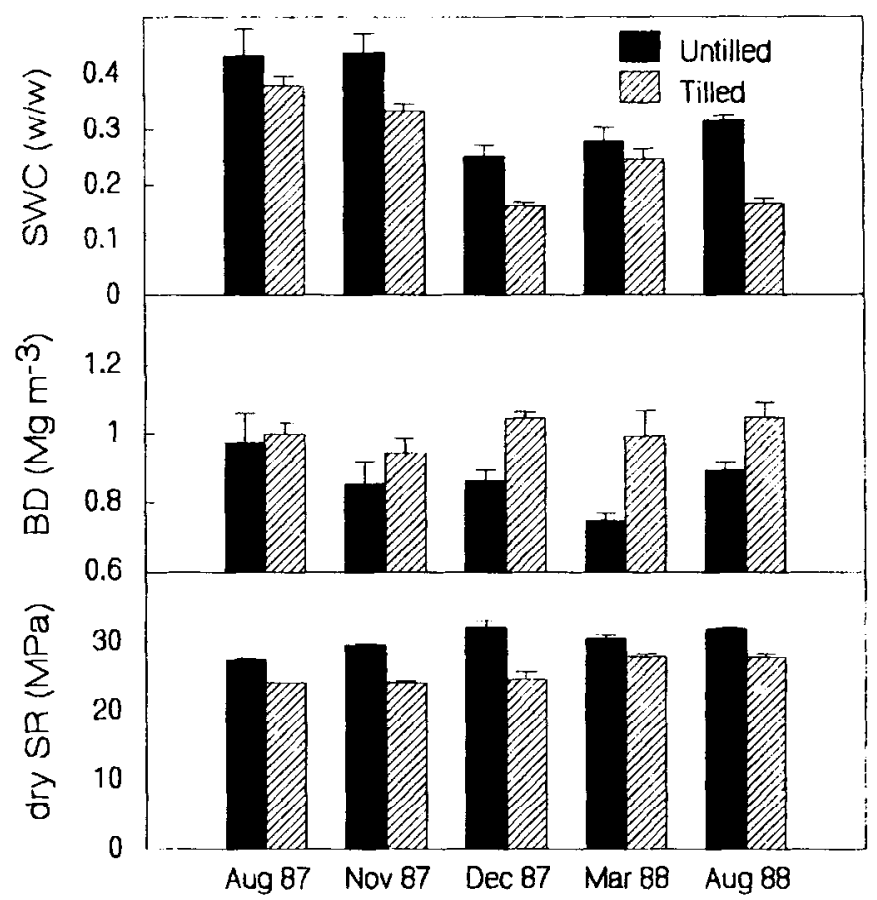

Fig. 5. Topsoil water content (SWC) (a), bulk density (BD) (b) and ovendry surface penetration resistance (dry $P R$ ) in soil type $C$ (typic Natralboll). Bars are standard errors.

\section{Conclusions}

The sowing of tall wheatgrass pastures produced variable responses in each soil type. The key factor was the different response to tillage of soils with variable surface horizon depths as each soil unit reacted differently to the replacement of the native grassland by tall wheatgrass. In soil type A, where the surface horizon is deepest, tillage caused minimal effects on soil properties and tall wheatgrass constituted an important component of the live vegetation at the time of this study ( 3 years after sowing). Soil types $B$ and $C$ have thinner surface horizons than soil type $A$ and were affected differently by tillage. These effects were positive in soil type B, a high sodic soil, and negative in soil type C, a slight sodic soil. Consequently, the survival of tall wheatgrass differed between these soil types.

Differences between soils and their reactions to tillage must be taken into account when deciding to replace a native grassland by sown pasture. Soils which occupy the same landscape, but differ in important properties may respond differently to tillage when a pasture is seeded. The predominance of each kind of sodiumaffected soil within the local heterogeneity pattern in the center of Buenos Aires Province is a major factor influencing the choice between continuing to maintain native grassland system or to replace them with seeded species such as tall wheatgrass.

\section{Literature Cited}

Batista, W.B., R.J.C. León, M.A. Taboada, and R.S. Lavado. 1993. Correspondence between grassland species composition and soil properties in the Southern Flooding Pampa, Argentina. Bull. Ecol. Soc. Amer. 74 Suppl: 157. 
Bowman, R.A., D.M. Mueller, and W.L. McGinnies. 1985. Soil and vegetation relationships in a Central Plains saltgrass meadow. J.R. Manage. 38:325-328.

Davidson, D.T. 1965. Penetrometer measurements. p. 472-484. In: C.A Black (ed.). Methods of Suil Analysis. Part 1. Agron. Soc. of Amer. Madison, Wisc.

Frelich, J.R., E.H. Jensen, and R.O. Gifford. 1973. Effect of crust rigidity and osmotic potential on emergence of six grass species. Agron. J. 65:26-29.

Gupta, R.K. and I.P. Abrol. 1990. Salt-affected soils: their reclamation and management for crop production. Adv. Soil Sci. 11:223-228.

Hidalgo, L.G., M.A. Cahuépè, and P.O. Rimoldi. 1989. Productividad primaria de una pastura de agropiro (Elytrigia elongata) y de una comunidad de pastizal natural, en condición similar de ambiente y manejo. Rev. Arg. Prod. Ann. Suppl. 9:39-40.

Hurlbert, S.H. 1984. Pseudoreplication and the design of ecological field experiments. Ecol. Monogr. 54:187-211.

Irigoyen, A. and N. Giambiaggi. 1990. Aspectos microbiologicos de un Natracual. Efecto del agropiro. Ciencia del Suelo 8:155-160.

Lavado, R.S. and M.A. Taboada. 1988. Soil water, salts, and sodium dynamics in a Natraquoll of Argentina. Catena 15:577-594.

Ludwig, J.R. and W.J. McGinnies. 1978. Revegetation trials on a saltgrass meadow. Agron. J. 31:308-311.

Maddaloni, J. 1986. Forage production on saline and alkaline soils in the humid region of Argentina. Reclam. Reveget. Res. 5:11-16.

Malcolm, C.V. 1986. Production from salt-affected soils. Reclam. Reveget. Res. 5:343-361.

Malcolm, C.V, and A.J. Clarke. 1973. Plant collection for saltland revegetation and soil conservation. Dept. Agr. W. Aust. Tech. Bull. No. $21.34 \mathrm{pp}$.
Malhi, S.S., D.W. McAndrew, and M.R. Carter. 1992. Effect of tillage and $\mathrm{N}$ fertilization of a Solonetzic soil on barley production and some soil properties. Soil Tillage Res. 22:95-107.

Montgomery, D.C. 1991. Design and analysis of experiments. J. Wiley \& Sons, Inc. New York, $589 \mathrm{pp}$

Mueller-Dombois, D. and H. Ellemberg. 1974. Aims and Methods of Vegetation Ecology. J. Wiley \& Sons, Inc. New York. $569 \mathrm{pp}$.

Mulholland, B. and M.A. Fullen. 1991. Cattle trampling and soil compaction on loamy sands. Soil Use Manage. 7:189-193.

Oesterheld, M. and R.J.C. León. 1987. El envejecimiento de las pasturas implantadas: su efecto sobre la productividad primaria. Turrialba 37:29-35.

Pearson, G.A. and L. Bernstein. 1958. Influence of exchangeable sodium on yield and chemical composition of plants: II. Wheat, barley, oats, rice, tall fescue, and tall wheatgrass. Soil Sci. 86:254-261.

Rengasamy, P. and K.A. Olsson. 1991. Sodicity and soil structure. Aust. J. Soil Res. 29:935-952.

Rengasamy, P., R.S.B. Greene, G.W. Ford, and A.H. Mehanni. 1984. Identification of dispersive behaviour and the management of redbrown carths. Aust. J. Soil Res. 22:413-431.

Rhoades, J.D. 1982. Soluble salts. p. 167-179 In: A.L. Page, R.H. Miller, and D.R. Keeney (Eds.). Methods of Soil Analysis, Part 2. American Society of Agronomy. Madison, Wisc.

Salazar Lea Plaza, J.C. and G. Moscatelli. 1989. Mapa de Suelos de la Provincia de Buenos Aires. SAG y P - INTA, Buenos Aires. 525 pp.

Szabolcs, I. 1988. Solonetz soils. p. 9-25. Proceedings of the International symposium on Solonetz Soils. Osijek, Yugoslavia. 